\title{
Deteksi Gen Ketahanan Hawar Daun Bakteri Xa21 pada Padi (Oryza Sativa L.) Hitam dan Merah Lokal Indonesia
}

\section{Detection of Bacterial Leaf Blight Resistance Genes Xa21 in Local Cultivars of Black and Red Rice in Indonesia (Oryza sativa L.)}

\author{
Andi Setiawan ${ }^{1}$, Alfino Sebastian ${ }^{2}$ dan Yekti Asih Purwestri ${ }^{1,2 \star)}$ \\ 1) Laboratorium Biokimia, Fakultas Biologi, Universitas Gadjah Mada \\ Jl. Teknika Selatan, Senolowo, Sinduadi, Mlati, Kabupaten Sleman, Yogyakarta 55281 \\ 2) Pusat Studi Bioteknologi, Universitas Gadjah Mada \\ Barek, Jalan Teknika Utara, Kocoran, Caturtunggal, Kec. Depok, \\ Kabupaten Sleman, Yogyakarta 55281 \\ *) Penulis untuk korespodensi E-mail: yekti@ugm.ac.id
}

Diajukan: 1 Juli 2018 /Diterima: 13 April 2021 /Dipublikasi: 25 Mei 2021

\begin{abstract}
Pigmented rice become popular consumed by the public as a functional food. However, there are factors limiting pigmented rice production, namely bacterial leaf blight caused by Xanthomonas oryzae pv. Oryzae (Xoo). The use of resistant varieties that have the Xa resistance gene is considered effective in overcoming the problem of decreasing rice yields. This Xa gene consists of several genes, one of which is a Xa21 gene. This study aims to determine the presence of the Xa21 bacterial leaf blight resistance gene in black rice cultivars Sembada Hitam, Cempo Ireng, Melik and Hitam Toraja and red rice cultivars of Aek sibondang, Merah Sumbawa, Segreng, and Pari Eja in Indonesia. The research methods included isolating the rice genome, checking the results of DNA isolation with agarose gel electro-foresis $(0.8 \%)$, measuring the concentration and purity of DNA, amplification of DNA using specific primers $X a 21$, and data analysis. The results of this study detected the presence of $\mathrm{Xa21}$ gene in all cultivars of black and red rice with resistant properties.
\end{abstract}

Keywords: black rice; BLB; red rice; Xa21 gene

\section{INTISARI}

Beras berpigmen mulai popular dikonsumsi oleh masyarakat sebagai bahan pangan fungsional. Tetapi, terdapat faktor pembatas produksi beras berpigmen yaitu penyakit hawar daun bakteri yang disebabkan oleh Xanthomonas oryzae pv. Oryzae (Xoo). Penggunaan varietas tahan yang memiliki gen ketahanan Xa dinilai efektif untuk menanggulangi masalah penurunan hasil padi. Gen Xa ini antara lain terdiri dari gen Xa21. Penelitian ini bertujuan untuk mengetahui keberadaan gen ketahanan hawar daun bakteri Xa21 pada padi hitam kultivar Sembada Hitam, Cempo Ireng, Melik dan Hitam Toraja serta padi merah kultivar Aek sibondang, Merah Sumbawa, Segreng, dan Pari Eja di Indonesia. Metode penelitian meliputi isolasi genom padi, pengecekan hasil isolasi DNA dengan elektroforesis gel agarosa $(0,8 \%)$, pengukuran konsentrasi dan kemurnian DNA, amplifikasi DNA primer pTA248, dan analisis 
data. Hasil penelitian ini mendeteksi keberadaan gen Xa21 pada semua kultivar padi hitam dan merah tersebut dengan dengan sifat tahan.

Kata kunci: gen Xa21; HDB; padi hitam; padi merah

\section{PENDAHULUAN}

Beras adalah makanan sereal yang menjadi makanan pokok di sebagian negara Asia. Beras yang paling umum dikonsumsi oleh manusia adalah beras putih (sekitar $85 \%$ ), dan sisanya adalah beras berpigmen. Beras berpigmen terutama beras hitam, beras merah dan beras ungu gelap. Beras ini berisi berbagai senyawa metabolit seperti flavon, tanin, fenolat, sterol, tocols, $y$-oryzanols, asam amino, dan minyak esensial. Antosianin, sekelompok flavonoid ungu kemerahan yang larut dalam air, dianggap sebagai komponen fungsional utama beras berpigmen (Deng et al., 2013).

Kebutuhan beras di Indonesia secara nasional tergolong tinggi, jika dilihat dari perhitungan angka kasar jumlah total penduduk dengan kebutuhan konsumsi beras per kapita per tahun. Berdasarkan data sensus penduduk 2020, penduduk Indonesia berjumlah 270,20 juta jiwa, sedangkan kebutuhan konsumsi beras per kapita adalah $114,8 \mathrm{~kg}$ per tahun (Badan Pusat Statistik, 2020). Dari data ini dapat diperoleh gambaran jumlah kebutuhan beras nasional per tahun yaitu sebesar 29,57 ton dan kelompok padi-padian masih menjadi sumber kalori utama penduduk Indonesia yaitu sebesar 38,42 persen dari total konsumsi. Namun terdapat faktor pembatas produksi padi yang bisa menurunkan produksi hasil panen dalam jumlah besar yaitu penyakit hawar daun bakteri yang disebabkan oleh Xanthomonas oryzae pv. oryzae (Xoo).
Penurunan produktivitas padi akibat serangan penyakit ini umumnya berkisar antara 15-23\% (Kadir, 2009).

Pergiliran varietas tahan perlu dirancang secara cermat untuk mengantisipasi perubahan strain Xoo dosdan agar ketahanan varietas dapat berfungsi dengan baik dan bertahan lebih lama (Ogawa 1993). Salah satu upaya yang dinilai efektif untuk mencegah penurunan hasil padi akibat serangan Xoo adalah dengan menanam varietas tahan yang mengandung gen ketahanan yaitu gen $X a$ karena bersifat ekonomis dan ramah lingkungan (Rao et al., 2003). Ketahanan varietas tanaman padi dipengaruhi oleh interaksi antara gen Xa dengan gen virulensi yang dimiliki oleh Xoo (Yamasaki et al., 2006). Sejauh ini terdapat 39 gen $X a$ yang telah diidentifikasi dari padi spesies liar dan padi budidaya (Khan et al., 2014 dalam Dossa et al., 2015). Beberapa gen Xa yang telah diidentifikasi antara lain adalah Xa21. Masing-masing gen Xa menghasilkan ketahanan yang berbeda terhadap masing-masing patotipe $X_{0 O}$. Pada penelitian yang dilakukan oleh Prasetya (2014), gen Xa21 memberikan respon tahan terhadap pathogen ras III dan VIII, dan memberikan respon agak tahan terhadap pathogen ras IV.

Di Indonesia terdapat banyak kultivar lokal padi hitam dan padi merah yang belum diketahui keberadaan gen Xa21 dan status ketahanannya. Pada penelitian yang dilakukan oleh Swamy et al. (2006), menyatakan bahwa 
gen Xa21 merupakan gen yang paling efektif terhadap resistensi Xoo. Studi yang dilakukan oleh Saumi (2017) juga mengungkap bahwa padi hitam kultivar Cempo Ireng dan Melik terdeteksi memiliki gen ketahanan hawar daun Xa21 dengan status ketahanan yang belum diketahui. Sementara itu, belum ada penelitian yang melaporkan keberadaan gen ketahanan hawar daun bakteri pada kultivar padi hitam dan padi merah lokal lainnya.

Berkaitan dengan masalah tersebut, studi ini dilakukan untuk mendeteksi keberadaan gen ketahanan terhadap hawar daun bakteri yaitu gen Xa21, serta status ketahananya pada kultivar padi lokal berpigmen di Indonesia. Penelitian dilakukan dengan mengelompokkan pita DNA hasil PCR gen Xa21, yang selanjutnya dikonstruksi sebuah dendrogram dengan menggunakan metode pengaklasteran Simple matching coefficient untuk menentukan tingkat kekerabatan gen Xa21 dari berbagai kultivar padi lokal berpigmen di Indonesia.

\section{BAHAN DAN METODE}

\section{Perkecambahan dan Penanaman Benih}

Benih padi disterilkan dengan larutan natrium hipoklorit 5,2\% selama 3 menit, dicuci tiga kali dengan akuades selama 5 menit, dan direndam dalam akuades selama 1 hari. Benih kemudian dibiarkan berkecambah, dan benih dibiarkan tumbuh pada media tanah sawah. Daun padi berumur empat minggu dipananen untuk dilakukan isolasi DNA.

\section{Isolasi DNA}

Sampel berupa daun padi $20 \mathrm{mg}$ digerus menggunakan nitrogen cair kemudian dilakukan estraksi DNA dengan menggunakan metode
DNA easy-kit (Qiagen). Sampel DNA kemudian disimpan di suhu $-20^{\circ} \mathrm{C}$.

\section{Pengamatan hasil Isolasi DNA dengan eletroforesis gel agarose}

Sebanyak $5 \mu \mathrm{L}$ sampel DNA dicampur dengan larutan $2 \mu \mathrm{L}$ loading dye di-running menggunakan Gel agarosa 0,8\% selama 30 menit pada voltase $100 \mathrm{~V}$ menggunakan alat elektroforesis (Mupid-exU). Selanjutnya agarose hasil elektroforesis divisualisasikan dengan UV-transilluminator (MicroDOC UVT254).

\section{Pengukuran konsentrasi dan kemurnian DNA}

DNA total yang telah berhasil diekstraksi kemudian diuji secara kuantitatif menggunakan spektrofotometer nanodrop (MN-913A Maestro Nano Pro), pada panjang gelombang $\lambda 230 \mathrm{~nm}$, $\lambda 260 \mathrm{~nm}$, dan $\lambda 280 \mathrm{~nm}$ (Surzycki, 2000).

\section{Amplifikasi Gen Xa21}

Amplifikasi gen Xa21 dilakukan dengan metode PCR (BioRad-T100 Thermal Cycler). Sebanyak $10 \mu \mathrm{l}$ dalam PCR tube dengan komposisi: $1 \mu \mathrm{l}$ DNA template, $1 \mu \mathrm{l}$ masing-masing primer gen pTA248 (Forward: 5'-AGACGCGGAAGGGTG GTTCCCGGA-3' dan reverse: 5'-AGACGCGG TAATCGAAGATGAA-3") $10 \mathrm{nM}, 5 \mu \mathrm{l}$ Bioline MIX PCR Kit, dan $2 \mu \mathrm{l}$ NFW (Nuclease Free Water). Program PCR yang digunakan adalah pre denaturasi $95^{\circ} \mathrm{C}$ selama 1 menit, kemudian diikuti dengan 30 kali siklus denaturasi $95^{\circ} \mathrm{C}$ selama 1 menit, annealing d $65^{\circ} \mathrm{C}$ selama 30 detik, extension $72^{\circ} \mathrm{C}$ selama 1 menit, dan final extension $72^{\circ} \mathrm{C}$ selama 10 menit. Setelah proses PCR selesai, produk PCR diruning dengan elektroforesis gel agarosa $2 \%$. Hasil elektroforesis divisualisasikan dengan UV- 
Translluminator dan didokumentasikan dengan gel doc camera (MicroDOC UVT254).

Analisis Kluster dan Konstruksi Dendogram

Analisis data dilakukan dengan membandingkan produk PCR hasil elektroforesis gel agarosa $2 \%$ dengan ukuran pita DNA standar yang digunakan (100bp). Penentuan ukuran pita DNA dihitung dengan menggunakan persamaan regresi antara log ukuran pita DNA standar $(Y)$ dengan nilai $\mathrm{Rf}(\mathrm{X})$ dari tiap-tiap pita DNA tanaman padi yang digunakan. Dari ukuran pita yang bervariasi dikelompokkan ke dalam 3 jenis, yang selanjutnya dilakukan analisis pengaklasteran berdasarkan Simple matching coefficient dengan program ClustalX ver. 1.8. Kemudian dari pengklasteran tersebut dibuat clustering matriks similaritas, dan selanjutnya dibuat dendrogram dari clustering tersebut menggunakan aplikasi MEGA Ver. 7.0.

HASIL DAN PEMBAHASAN
Ekstraksi DNA merupakan langkah awal prosedur kerja dalam genetika molekular untuk mendapatkan DNA dari suatu organisme tanpa debris sel. Pada penelitian ini dilakukan ekstraski DNA yang kemudian dilajutkan dengan deteksi gen Xa21 untuk mengetahui potensi ketahanan padi lokal berpigmen terhadap penyakit hawar daun.

\section{Hasil Kualitatif dan Kuantitatif Isolasi DNA Daun Padi}

DNA yang telah diperoleh dari proses ekstraksi DNA diuji kualitasnya secara kualitatif dengan metode elektroforesis menggunakan media gel agarose $0,8 \%$. Elektroforesis adalah suatu cara analisis kimiawi yang didasarkan pada pergerakan molekul-molekul bermuatan di dalam medan listrik. Pergerakan molekul dalam medan listrik dipengaruhi oleh bentuk, ukuran, besar muatan dan sifat kimia dari molekul (Titrawani, 1996)

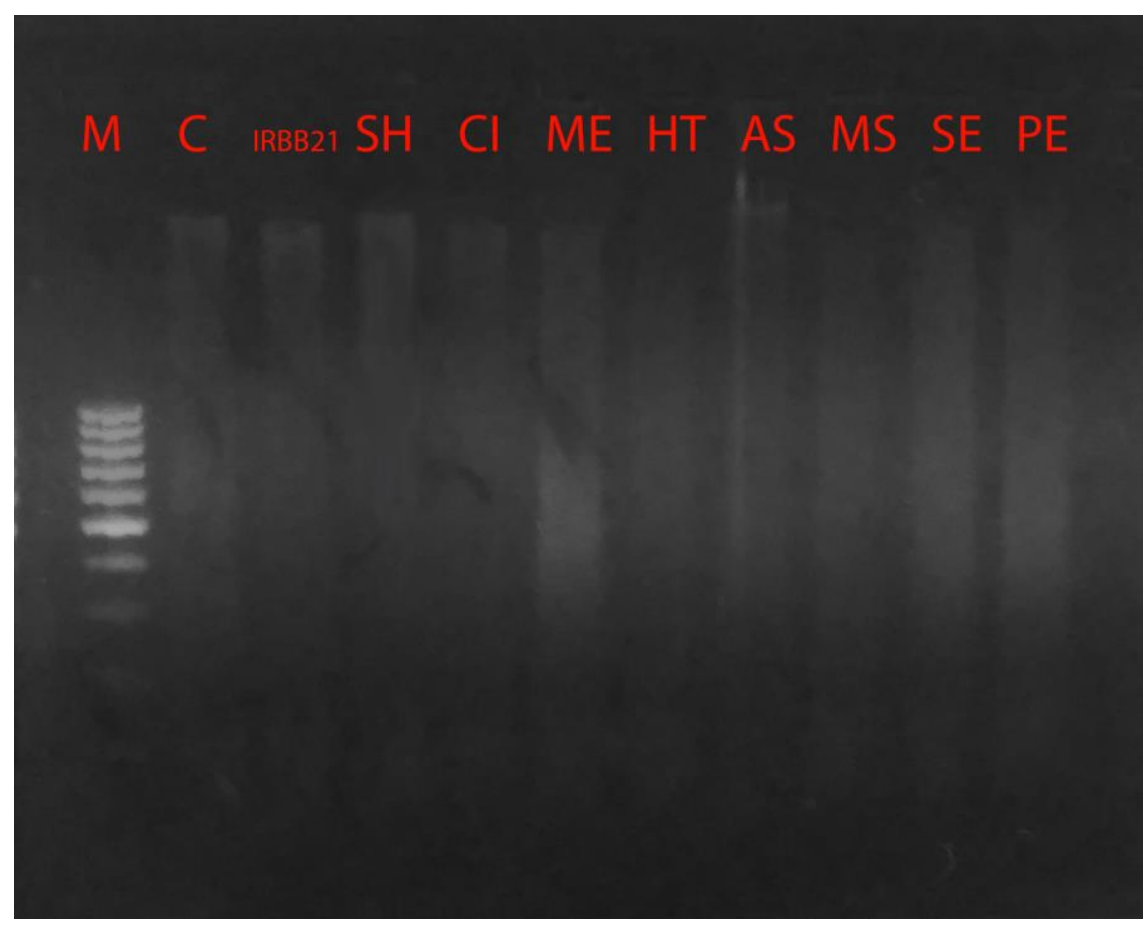

Keterangan: $\mathrm{M}=$ Marker 100 bp, $\mathrm{C}=$ Ciherang, $\mathrm{SH}=$ Sembada Hitam, $\mathrm{Cl}=$ Cempo Ireng, $\mathrm{ME}=$ Melik, $\mathrm{AS}=$ Aek Sibondang, $\mathrm{MS}=$ Merah Sumbawa, SE = Segreng, dan PE = Pari Eja. 
Gambar 1. Elektroforegram isolasi genom padi. Seluruh sampel menunjukkan band yang relatif sama yang mengindikasikan keberhasilan dalam mengisolasi DNA Genom.

Prinsip pergerakan fragmen DNA berdasarkan pada muatan negatif molekul DNA yang berpindah melalui gel agarosa menuju muatan positif. Gel agarosa yang memiliki tekstur semisolid memiliki pori-pori yang dapat menghalangi perpindahan fragmen DNA. Ukuran fragmen DNA yang lebih besar bermigrasi lebih lambat karena memiliki gesekan yang lebih besar dengan agarose menyebabkan migrasi melalui pori menjadi tidak seefektif fragmen DNA yang berukuran kecil (Sambrook \& Russell, 2001). Hasil isolasi genom padi disajikan dalam bentuk elektro-foregram (gambar 1). Marker yang digunakan yaitu DNA ladder $100 \mathrm{bp}$.

Proses ekstraksi DNA telah berhasil mengisolasi DNA genom dari daun padi. Hal ini ditunjukkan dengan adanya pita DNA genom padi pada seluruh sumuran gel agarosa $0,8 \%$ dengan ukuran yang sama untuk seluruh kultivar padi. Pita DNA yang tebal dan mengumpul (tidak menyebar) menunjukkan konsentrasi yang tinggi dan DNA total yang diekstrak dalam kondisi utuh. Sedangkan, pita DNA yang terlihat menyebar menunjukkan adanya ikatan antar molekul DNA yang terputus pada saat proses ekstraksi berlangsung, sehingga DNA genom terpotong menjadi bagian-bagian yang lebih kecil. Terputusnya ikatan antar molekul tersebut dapat disebabkan oleh adanya gerakan fisik yang berlebihan yang dapat terjadi pada proses pemipetan, disentrifus, atau bahkan temperatur yang terlalu tinggi dan karena aktivitas bahanbahan kimia tertentu (Irmawati, 2003). Selain itu menyatakan bahwa adanya smear menunjukkan masih terdapat RNA yang mengkontaminasi isolat DNA. Adanya RNA dapat terjadi karena pada metode isolasi DNA yang dilakukan tidak digunakan RNAse yang berfungsi untuk menghilangkan kontaminan RNA (Farrel, 2010).

Tabel 1. Pengukuran DNA padi secara kuantitatif

\begin{tabular}{lcc}
\hline \multicolumn{1}{c}{ Sampel DNA } & Konsentrasi DNA $(\mathrm{ng} / \mu \mathrm{l})$ & Kemurnian DNA \\
\cline { 3 - 3 } & & $($ A260/A280) \\
\hline Ciherang & 438,44 & 2,153 \\
SembB21 & 582,18 & 1,898 \\
Cempo Ireng & 404,04 & 2,010 \\
Melik & 379,51 & 2,086 \\
Hitam Toraja & 555,48 & 1,987 \\
Aek Sibondang & 463,57 & 2,054 \\
Merah Sumbawa & 402,18 & 2,127 \\
Segreng & 235,21 & 1,975 \\
Pari Eja & 378,93 & 1,980 \\
\end{tabular}


Uji kuantitatif DNA genom dilakukan dengan menggunakan spektrofotometer nanodrop untuk megetahui konsentrasi dan kemurnian DNA genom padi hasil isolasi. Berdasarkan penelitian yang telah dilakukan, konsentrasi dan kemurnian DNA genom yang diperoleh dapat dilihat pada tabel 1 .

Kemurnian DNA berguna untuk melihat ada tidaknya kontaminan DNA yang berupa RNA dan protein. Pengukuran kemurnian dengan menggunakan spektrofotometer dapat ditentukan dengan cara menghitung rasio antara nilai $260 \mathrm{~nm}$ dan $280 \mathrm{~nm}$ pada sampel DNA. Nilai $260 \mathrm{~nm}$ merupakan nilai maksimal DNA dapat menyerap cahaya, nilai tersebut dapat digunakan untuk memperkirakan konsentrasi DNA, sedangkan nilai $280 \mathrm{~nm}$ merupakan nilai maksimal residu protein dapat menyerap cahaya.

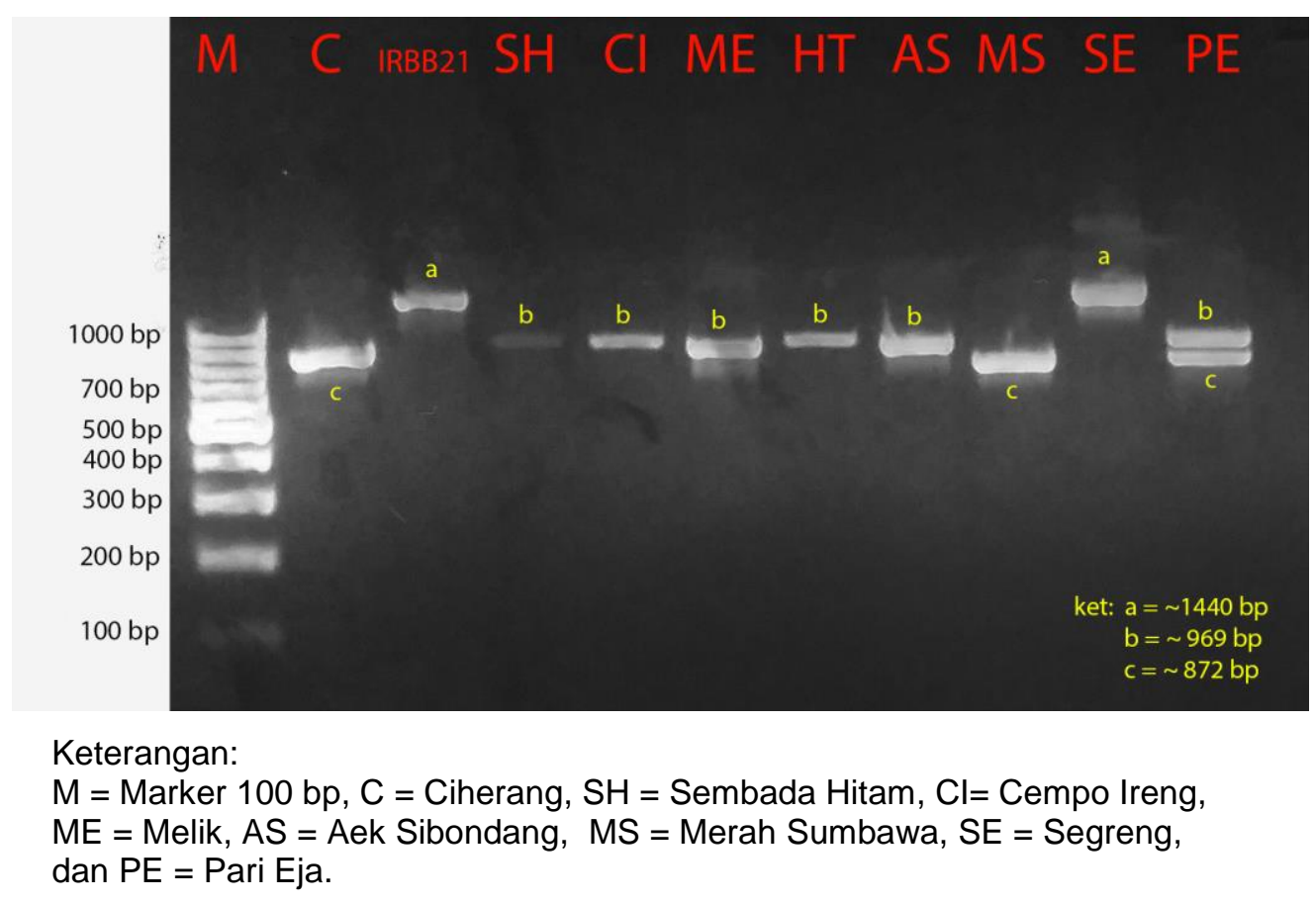

Gambar 2. Elektroforegram hasil amplifikasi gen Xa21. Terdapat 3 kelompok ukuran band yaitu $\sim 1440 \mathrm{bp}, \sim 969 \mathrm{bp}$, dan 872 bp.

Berdasarkan hasil pengukuran spektrofotometri menunjukkan tingkat kemurnian sampel DNA, masing-masing sampel berkisar antara 1,821 hingga 2,153. Hasil ekstraksi dengan rasio 1,8 sampai 2,0 merupakan DNA dengan kemurnian yang tinggi dan tidak terkontaminasi dengan residu protein. Kisaran angka tersebut telah memenuhi persyaratan yang dibutuhkan dalam analisis molekuler. Hasil yang menunjukkan nilai kemurnian di bawah 1,8 menunjukkan masih adanya kontaminan protein, sedangkan hasil ekstraksi dengan kemurnian di atas 2,0 menunjukkan adanya kontaminan senyawa berat molekul kecil misalnya RNA, sehingga diperlukannya adanya purifikasi dengan RNAse. DNA yang tidak murni disebabkan juga oleh adanya sisa-sisa etanol pada saat pengeringan yang tidak menyeluruh. Faktor lain yang menyebabkan DNA tidak murni adalah adanya sisa kandungan metabolit sekunder 
pada organ tanaman yang diekstrak Sambrook \& Russel (2001).

Konsentrasi yang didapatkan pada tahap ekstraksi memiliki berkisar antara 235,21 ng/ $\mu \mathrm{L}$ hingga $582,18 \mathrm{ng} / \mu \mathrm{L}$, tiap kultivar setidaknya memerlukan konsentrasi di atas $40 \mathrm{ng} / \mu \mathrm{L}$ cukup untuk digunakan dalam tahap amplifikasi DNA menggunakan penanda molekuler SCAR berda-

Tabel 2. Kelompok ukuran pita hasil amplifikasi gen Xa21

\begin{tabular}{cll}
\hline Kelompok & Ukuran band $(\mathrm{bp})$ & \multicolumn{1}{c}{ Kultivar padi } \\
\hline A & $\sim 1440$ & IRBB21 \\
& & Segreng \\
\hline B & Sembada Hitam \\
& Cempo Ireng \\
& Melik \\
& Hitam Toraja \\
& & Aek Sibondang \\
& & Pari Eja \\
\hline C & Ciherang \\
& Merah Sumbawa \\
& & Pari Eja \\
\hline
\end{tabular}

sarkan protokol Priya et al., (2016) kisaran konsentrasi DNA yang bervariasi ini disebabkan oleh perbedaan kualitas daun yang tersedia untuk diekstrak DNAnya, selain itu DNA genom yang diekstrak tidak semua dapat diambil karena banyak hasil penggerusan yang tidak terpindahkan ke dalam microtube.

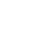

\section{Deteksi Gen Xa21}

Deteksi gen ketahanan terhadap hawar daun bakteri yaitu Xa21 pada 4 kulivar lokal padi hitam Sembada Hitam, Cempo Ireng, Melik, dan Hitam Toraja, serta 4 kultivar lokal padi merah yaitu Aek Sibondang, Merah Sumbawa, Segreng, dan Pari Eja, serta 2 kultivar padi putih yaitu Ciherang dan IRBB21 menggunakan metode PCR dengan primer pTA248.

Hasil amplifikasi DNA untuk mendeteksi gen Xa21 pada tiap kultivar padi disajikan dalam bentuk elektroforegram (Gambar 2). Elektroforegram hasil amplifikasi gen Xa21 menunjukkan bahwa semua sampel padi teramplifikasi 
Primer pTA248 merupakan penanda STS berbasis PCR untuk penandaan gen Xa21. Primer pTA248 menguatkan fragmen $\sim 0.9 \mathrm{~kb}$ pada fragmen yang tahan (resisten) dan 600700 bp dalam genotip rentan (Sundaram et al., 2011). Salah satu keunggulan marka STS yaitu bersifat kodominan (bisa dibedakan alel heterozigot dan homozigot). Sesuai dengan penelitian Sundaram et al. (2016), amplifikasi gen dominan Xa21 menggunakan primer pTA248 (tipe STS) yang dapat mengamplifikasi gen Xa21 pada ukuran 950 bp sebagai penanda sifat resistant (tahan) dan ukuran 660 bp sebagai penanda sifat susceptible (rentan).

Dalam penelitian ini, hasil amplifikasi gen Xa21 dengan menggunakan primer pTA248 menunjukkan adanya variasi ukuran pita yang mendekati ukuran penanda sifat tahan (950bp). Variasi ukuran pita tersebut yang dikelompokkan menjadi tiga kelompok ukuran pita $\mathrm{A}, \mathrm{B}$ dan $\mathrm{C}$, seperti terlihat pada tabel 4. Kelompok ukuran pita A yang teramplifikasi pada ukuran pita sekitar 1440 bp terdeteksi pada padi kultivar IRBB21 dan Segreng. Kelompok ukuran pita B yang teramplifikasi pada ukuran pita sekitar 969 bp terdeteksi pada padi kultivar Sembada Hitam, Cempo Ireng, Melik, Hitam Toraja, Aek Sibondang, dan Pari Eja. Sedangkan kelompok ukuran pita $\mathrm{C}$ yang teramplifikasi pada ukuran pita sekitar 872 bp terdeteksi pada padi kultivar Ciherang, Merah Sumbawa, serta Pari Eja

Pengelompokan ukuran pita dilakukan karena adanya variasi ukuran pita pada kesepuluh sampel yang diujikan. Dan variasi ukuran pita yang muncul keseluruhannya terdapat pada ukuran pita untuk penanda sifat tahan yaitu 950 bp. Sehingga, hal ini menunjukkan bahwa pada keseluruhan sampel uji terdapat gen ketahanan hawar daun bakteri Xa21 dengan sifat tahan. Pengelompokan ukuran pita yang terdiri dari tiga kelompok menunjukkan bahwa dalam penelitian ini, gen ketahanan hawar daun bakteri Xa21 dengan sifat tahan yang terdiri atas 3 jenis.

Berdasarkan pengelompokan yang terdiri dari 3 jenis kelompok pada sepuluh kultivar padi, disusun ke dalam tabel $n \times t$. Selanjutnya dilakukan penyusunan matriks similaritas berdasarkan Simple matching coefficient, yang disusun berdasarkan tabel $\mathrm{n} \times \mathrm{t}$ tersebut. Penggunaan Simple matching coefficient untuk menentukan nilai pada matriks similaritas ini digunakan karena pada Simple matching coefficient berdasarkan pertimbangkan pada sifat double negative, sehingga hasilnya lebih akurat dibandingkan dengan metode lain.

Clustering analysis didapatkan dengan metode penghitungan algoritma pengklasteran. Algoritma pengklasteran yang digunakan adalah average linkage, yaitu nilai penyatuan dua strain atau lebih berada pada nilai rata-ratanya. Dari penghitungan dengan menggunakan average linkage didapatkan pada level tertentu akan terjadi peleburan strain yang diidentifikasi. Dari analisis pengklasteran didapatkan clustering matriks similaritas, yang selanjutnya dari clustering matriks similaritas tersebut didapatkan dendrogram. Dendrogram seperti pada gambar 7 merupakan hasil dari clustering matriks similaritas, yang menunjukkan tingkat kekerabatan dai kultivar padi yang diujikan.

Dendrogram pada gambar 3 menunjukkan bahwa padi kultivar 'Ciherang' memiliki kekerabatan dengan kultivar 'Merah Sumbawa', 
kemudian padi IRBB21 memiliki kekerabatan dengan kultivar 'Segreng', serta 5 kultivar padi yaitu 'Sembada Hitam', 'Cempo Ireng', 'Melik', 'Hitam Toraja', dan 'Aek Sibondang' juga memiliki kekerabatan yang dekat. Sedangkan padi kultivar 'Pari Eja' memiliki kekerabatan yang agak jauh dengan kesemua kultivar dalam penelitian ini, hal ini juga terlihat dari hasil amplifikasi yang adanya kemunculan 2 pita pada kultivar ini. Kekerabatan yang ditujukkan dalam dendrogram pada gambar 3 merupakan kekerabatan berdasarkan keberadaan gen ketahanan Xa21 dengan sifat tahan.

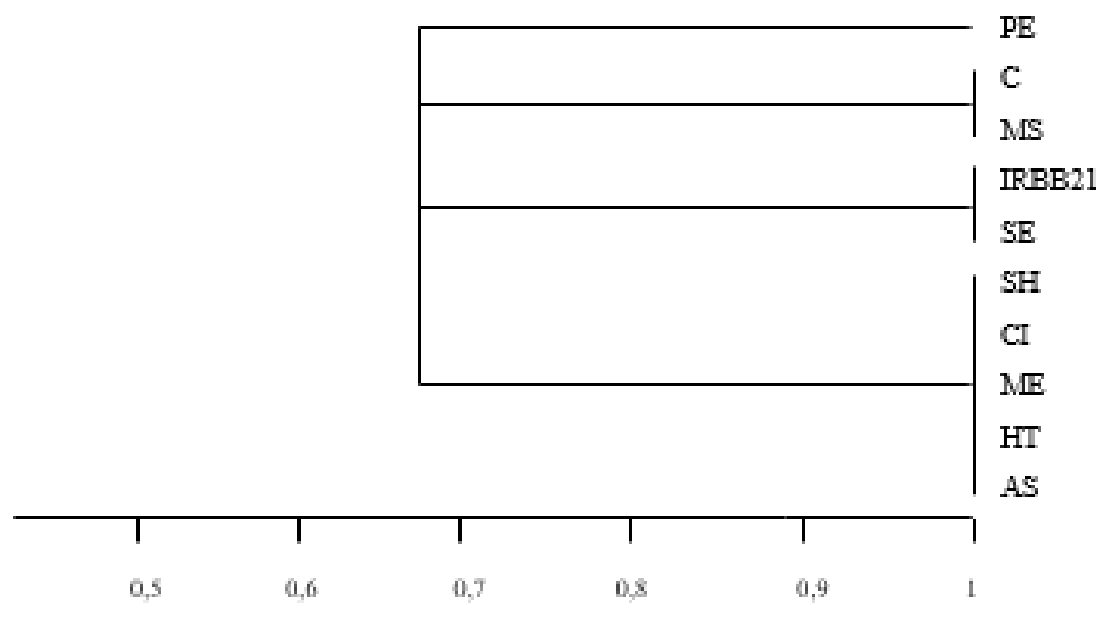

Keterangan:

$\mathrm{C}=$ Ciherang, $\mathrm{SH}=$ Sembada Hitam, $\mathrm{Cl}=\mathrm{Cempo}$ Ireng, $\mathrm{ME}=$ Melik, $\mathrm{AS}=$ Aek Sibondang, MS = Merah Sumbawa, SE = Segreng, dan PE = Pari Eja.

Gambar 3. Dendrogram hasil analisis pengklasteran. Terdapat 3 kelompok utama, yaitu kelompok A, B, C yang mengindikasikan kelompok jenis ketahanan yang berbeda-beda.

Gen Xa21 merupakan gen yang dipindahkan dari spesies liar Oryza longistaminata ke IR24, menghasilkan garis isogenik dekat, yaitu IRBB21. Dalam tes untuk ketahanan penyakit, IRBB21 telah dilaporkan resisten terhadap banyak strain Xoo dari Filipina dan India (Swamy et al., 2006). Dalam penelitian ini digunakan padi IRBB21 sebagai kontrol positif untuk deteksi gen Xa21. Hal ini didukung dengan penelitian yang dilakukan oleh Wang et al. (1994) bahwa IRBB21 memiliki gen Xa21 yang bersifat tahan. Pada penelitian ini, IRBB21 dikelompokkan ke dalam kelompok ukuran pita
A yaitu dengan ukuran pita sekitar $1440 \mathrm{bp}$. Dengan demikian dalam penelitian ini IRBB21 mempunyai gen ketahanan hawar daun Xa21 dengan sifat tahan jenis $A$ atau jenis pertama.

Kultivar padi Segreng yang digunakan dalam penelitian ini merupakan padi merah yang berasal dari daerah Gunung Kidul, Yogyakarta. Kultivar Segreng merupakan padi gogo unggul lokal dari Gunung Kidul. Status ketahanan padi kultivar ini terhadap hawar daun bakteri belum diketahui, keberadaan gen ketahanannya juga belum diketahui. Pada penelitian ini, hasil amplifikasi terhadap padi kultivar Segreng 
masuk ke kelompok ukuran pita $A$, bersamaan dengan hasil IRBB21. Dengan demikian dapat diketahui padi kultivar Segreng memiliki gen Xa21 dengan sifat tahan seperti IRBB21 yaitu jenis $A$ atau jenis pertama.

Pada penelitian ini, padi kultivar Sembada Hitam, Cempo Ireng, dan Hitam Toraja, Melik, dan Aek Sibondang teramplifikasi dengan ukuran pita yang masuk dalam kelompok ukuran pita B yaitu dengan ukuran pita sekitar 969 bp. Dari penelitian yang dilakukan oleh Saumi (2017) yang juga melakukan pendeteksian gen ketahanan hawar daun Xa21, didapatkan hasil bahwa padi kultivar Cempo Ireng dan Melik terdeteksi memiliki gen ketahanan terhadap hawar daun bakteri Xa21, namun dengan status yang belum diketahui. Sesuai dengan penelitian tersebut, dalam penelitian ini kedua kultivar tersebut juga terdeteksi gen ketahanan hawar adaun bakteri Xa21 dengan sifat tahan. Dengan demikian kelima padi kultivar tersebut memiliki gen ketahanan hawar daun bakteri Xa21 dengan sifat tahan jenis $B$ atau jenis kedua.

Ciherang merupakan varietas padi yang tahan terhadap wereng coklat biotipe 2 dan agak tahan biotipe 3. Padi Ciherang baik ditanam di lahan sawah irigasi dataran rendah sampai 5000 m dpl. Wening et al. (2016) mengatakan bahwa Ciherang memiliki ketahanan terhadap hawar daun bakteri strain III dan IV. Pada penelitian ini digunakan kultivar local Ciherang yaitu dari Sleman sebagai pembanding. Padi kultivar Merah Subawa merupakan padi merah yang berasal dari daerah Sumbawa, Nusa Tenggara Barat. Belum ada penelitian mengenai kultiavaar padi tersebut. Hasil amplifikasi didapatkan ukuran pita yang menunjukkan padi kultivar
Ciherang dan Merah Sumbawa masuk ke kelompok ukuran pita $\mathrm{C}$, yaitu dengan ukuran pita sekitar 872 bp. Dengan demikian padi kultivar Ciherang dan Merah Subawa tersebut memiliki gen ketahanan hawar daun bakteri Xa21 yang bersifat tahan jenis $C$ atau jenis ketiga.

'Pari Eja' merupakan kultivar padi merah yang berasal dari daerah Kalimantan. Status ketahanan terhadap hawar daun bakteri pada padi kultivar ini belum diketahui, hal ini karena belum banyak penelitian mengenai kultivar padi ini. Pada penelitian ini, didapatkan bahwa hasil amplifikasi terdapat dua ukuran pita yang berbeda. Hasil tersebut membuat padi kultivar Pari Eja ini dapat dikelompokkan ke dalam kelompok ukuran pita B dan juga C. Dengan demikian padi kultivar Pari Eja diduga memiliki 2 jenis gen ketahanan hawar daun bakteri Xa21 dengan sifat tahan yaitu jenis $B$ dan $C$ atau jenis kedua dan ketiga.

Adanya variasi ukuran pita dari gen Xa21 yang terdeteksi di sepuluh tanaman padi yang digunakan diduga dikarenakan adanya polimorfisme pada gen ini. Hal ini didukung dengan primer yang digunakan bertipe STS yang mampu mendeteksi polimorfisme dan bersifat kodominan. Selain itu, adanya polimorfisme pada pada gen Xa21 didukung dengan penelitian sebelumnya yang dilakukan oleh Swamy et al., (2006) bahwa hasil amplifikasi gen Xa21 dengan menggunakan marker pTA248 menampilkan adanya polimorfisme. Namun, dalam penelitian ini tidak dilakukan pengecekan polimorfisme sehingga untuk mengetahui polimorfisme pada gen Xa21 
perlu dilakukan sekuensing atau penentuan urutan nukleotida penyusunnya.

Kombinasi beberapa gen ketahanan $\mathrm{Xa}$ dalam satu kultivar padi akan meningkatkan ketahanan padi terhadap Xoo sebagaimana Nafisah et al., (2007) menyebutkan tanaman padi yang memiliki lebih banyak gen $X a$ di dalam satu tanaman memiliki ketahanan yang lebih tinggi, sehingga tingkat ketahanan tanaman bisa lebih panjang. Selain itu, pada penelitian ini hanya dilakukan deteksi gen dalam 4 kultivar padi hitam dan 4 kultivar padi merah. Oleh karena itu, perlu dilakukan penelitian lanjut untuk melihat ekspresi gen $X a$ dan skrining untuk gen Xa lainnya.

\section{KESIMPULAN}

Kultivar padi yang diteliti memiliki gen ketahanan hawar daun bakteri (HDB) Xa21 dengan sifat tahan (resisten), yang terdiri dari 3 kelompok ukuran gen 1440 bp, 969 bp dan $\sim 872$ bp. IRBB21 mempunyai gen ketahanan hawar daun Xa21 dengan sifat tahan jenis $A$ ( 1440 bp) atau jenis pertama. Kultivar Sembada Hitam, Cempo Ireng, Hitam Toraj, Melik, dan Aek Sibondang teramplifikasi dengan ukuran pita yang masuk dalam kelompok ukuran pita B ( 969 bp). Kultivar Ciherang dan Merah Subawa memiliki gen ketahanan hawar daun bakteri Xa21 yang bersifat tahan jenis C ( 872 bp) atau jenis ketiga. Kultivar Pari Eja dikelompokkan ke dalam kelompok ukuran pita $B$ dan juga $C$, sehingga kultivar Pari Eja diduga memiliki 2 jenis gen ketahanan hawar daun bakteri Xa21 dengan sifat tahan yaitu jenis $B$ dan C atau jenis kedua dan ketiga. Penelitian lanjutan perlu dilakukan untuk mendeteksi gen Xa lainnya pada semua kultivar padi lokal berpigmen tersebut. Selain itu, perlu dilakukan sekuensing untuk mengetahui polimorfisme pada gen Xa21.

\section{UCAPAN TERIMA KASIH}

Penulis mengucapkan terima kasih kepada teman-teman di Laboratorium Rekayasa Genetika PAU UGM yang telah banyak membantu penulis dari awal penelitaan sampai penelitian selesai.

\section{DAFTAR PUSTAKA}

Badan Pusat Statistika. Data sensus penduduk Tahun 2020. www.bps.go.id. Diakses pada 10 Maret 2021.

Deng, G.F., X.R. Xu, Y. Zhang, Li, R.Y. Gan, \& H.B. Li. 2013. Phenolic compounds and bioactivities of pigmented rice. Critical Reviews in Food Science and Nutriton. 53:296-306.

Dossa, G.S., A. Spark, C.V. Cruz, and R. Olivia. 2015. Decision tools for bacterial blight resistance gene deployment in ricebased agricultural ecosystems. Frontiers in Plant Science. 6(305):1-5.

Farrel, R. E. 2010. RNA Methodologies. Academic Press. London.

Irmawati. 2003. Perubahan Keragaman Genetik Ikan Kerapu Tikus Generasi Pertama Pada Stok Hatchery. Thesis. Bogor: IPB.

Kadir, T.S. 2009. Menangkal HDB dengan menggilir varietas. Warta Penelitian dan Pengembangan Pertanian. 31(5):1-3. 
Khan, M.A., M. Naeem, and M. Iqbal. 2014. Breeding approaches for bacterial leaf blight resistance in rice (Oryza sativa L.) current status and future directions. European Journal Plant Pathology. 139:27-37.

Nafisah, A.A., B. Daradjat, Suprihatno, dan T.S. Kadir. 2007. Ketahanan padi terhadap hawar daun bakteri. Penelitian Pertanian Tanaman Pangan. 26(2):100-105.

Ogawa, T. 1993. Methods and strategy for monitoring race distribution and identification of resistance genes to bacterial leaf blight (Xanthomonas campestris pv. oryzae) in rice. JARQ. 27: $71-80$.

Prasetya, O. W. 2014. Identifikasi Marka Gen Ketahanan Hawar Daun Bakteri Pada Galur Padi Introduksi dan Galur Dihaploid. Tesis. Program Studi Biologi Tumbuhan. Sekolah Pascasarjana Institut Pertanian Bogor. Bogor

Priya, P. R., Selastin Antony, R., Gopalaswamy, G. et al. 2016. Development of sequence-characterized amplified region (SCAR) markers as a quality standard of inoculants based on Azospirillum. Arch Microbiol, 198:257-267.

Rao, K.K., K.K. Jena, and M.L. Narasu. 2003. Molecular Tagging of a New Bacterial Blight Resistence Gene in Rice Using RAPD and SSR Markers.
Sambrook J, Russell DW. 2001. Molecular Cloning: A Laboratory Manual. 3rd edition. Laboratory Pr. New York.

Saumi, R. 2017. Deteksi Gen Ketahanan Hawar Daun Bakteri Xa7 Dan Xa21 Pada Tiga Kultivar Lokal Padi Hitam (Oryza Sativa L.) di Yogyakarta. Skripsi. Yogyakarta: Universitas Gadjah Mada.

Sundaram, R.M., Laha, G.S., Viraktamath, B.C., Sujatha, K., Natarajkumar, P., Hari, Y., Srinivasa Rao, K., Reddy, C.S., Balachandran, S.M., Madhav, M.S., Hajira, S.K., Rani N.S., Vishnupriya, M.R and Sonti, R.V. 2011. Marker Assisted Breeding For Development Of Bacterial Blight Resistant Rice. In: K. Muralidharan and E.A. Siddiq (eds.) Genomics and Crop Improvement: Relevance and Reservations, Institute of Biotechnology, Acharya NG Ranga Agricultural University, Hyderabad 500030 India (pp: 154-182).

Surzycki, S. 2000. Basic Techniques in Molecular Biology. Springer-Verlay. Berlin Heidelberg. Germany.

Swamy, P., Panchbhai, A. N., Dodiya, P., Naik, V., Panchbhai, S. D., Zehr, U. B., Char, B. R. 2006. Evaluation of bacterial blight resistance in rice lines carrying multiple resistance genes and $\mathrm{Xa21}$ transgenic lines. Current Science. 90(6):818-824.

Titrawani. 1996. Biodiversiti Kodok Genus Rana Ditijau dari Morfologi, Kariotip dan Pola Protein di Kodya Sawahlunto. Program 
Pasca Sarjana. Institut Pertanian Bogor.

Bogor.

Wang G., Mackill DJ, Bonman JM, Mccouch SR and Champoux MC. 1994. RFLP mapping of genes conferring complete and partial resistance to blast in a durably resistant rice cultivar. Genetics. 136:1421-1434.

Wening, R. H., \& Susanto, U. 2016. Varietas Unggul Padi Tahan Hawar Daun Bakteri: Perakitan dan Penyebaran di Sentra Produksi Developed Bacterial Leaf Blight Resistant Rice Variety : Its Breeding and Adoption in the Production Center Areas. Iptek Tanaman Pangan, 11(2):119-126.

Yamasaki, R.A.D, N. Murata, and T. Suwa. 2006. Studies on the culture of Xanthomonas oryzae. Joernal Bacteriol, 42:946-949. 